\title{
Commemorative Urban Practices and Gender Equality: The Case of Santiago de Compostela's Urban Anthroponymy
}

\author{
Prácticas Conmemorativas Urbanas e Igualdad de Género: El Caso \\ de la Antroponimia Urbana de Santiago de Compostela
}

\section{María Novas Ferradás ${ }^{1}$}

Fecha de recepción: 28-03-20 - Fecha de aceptación: 20-07-2018

Hábitat y Sociedad (ISSN 2173-125X), n. ${ }^{\circ} 11$, noviembre de 2018, pp. 109-129.

http://dx.doi.org/10.12795/HabitatySociedad.2018.i11.07

\section{Summary}

For centuries, decision-making procedures in commemorative urban practices have established a methodology of recognition relying on an androcentric process which has implied exclusion mechanisms. Structures of economic and dominating cultural power favoured the interests of a privileged minority, while penalizing, limiting and constraining the inclusion and visibility of a wide range of human beings, mainly women. This bias was historically questioned by feminist theory and gender mainstreaming policies, which focus on how different gender gaps affect women in order to improve the standard of justice, progress and dignity of all people in different territories. Through a study of Santiago de Compostela's urban anthroponymy, we will discuss how differences between social groups still persist, exploring, if applicable, how to produce effective changes that potentially resolve situations of inequality.

Other forms of imagination and resistance can emerge at a symbolic level also, including in the way the streets of our cities are named.

\section{Key words}

Equality; Feminism; Gender; Street names; Anthroponymy; Women

\section{Resumen}

Durante siglos, los procesos de toma de decisión en las prácticas urbanas conmemorativas han establecido una metodología de reconocimiento basada en un sesgo androcéntrico que ha implicado mecanismos de exclusión y cierre. Las estructuras del poder han favorecido los intereses particulares de una minoría privilegiada, penalizando, limitando y conteniendo la inclusión y visibilidad de la diversidad humana de nuestras ciudades. Este sesgo histórico ha sido cuestionado por la teoría feminista y las políticas de igualdad, centradas en el estudio de las distintas desigualdades de género que afectan a las mujeres con el fin de promover estándares de justicia, progreso y dignidad para todas las personas en los diferentes territorios. A través del estudio de la antroponimia urbana de Santiago de Compostela analizaremos las prácticas conmemorativas urbanas, discutiendo, de ser el caso, cómo producir cambios efectivos que resuelvan las potenciales situaciones de desigualdad.

Otras formas de imaginación y resistencia pueden emerger, también en un nivel simbólico, incluso en la manera en la que las calles de nuestras ciudades son denominadas.

Pallabras clave

Igualdad; Feminismo; Género; Calles; Antroponimia; Mujeres

1 Arquitecta y doctoranda en Arquitectura en la Universidad de Sevilla (España); investigadora invitada en el Departamento de Arquitectura de la Universidad Técnica de Delft (Países Bajos). 


\section{Introduction}

\section{A Critical Engagement of Toponymic Inscription}

The social and cultural understanding of urban spaces is unavoidable in new critical approaches to cities that may result in potential transformations towards the construction of more inclusive and fair territories. Gender inequalities and power imbalances between social groups can still be found at every level of cultural production, as well as in architectural and urban discourse, such as "in its rituals of legitimation, classification systems, lecture techniques, publicity images, canon formation, division of labour, bibliographies, design conventions, legal codes, salary structures, publishing practices, language, professional ethics, editing protocols, project credits, etc." (Wingley, 1992, p. 329). Different approaches to the symbolic order of urbanism and architecture narratives are increasingly emerging as a form of imaginative resistance, opposing those from traditional, autonomous and authoritarian perspectives which are still the norm.

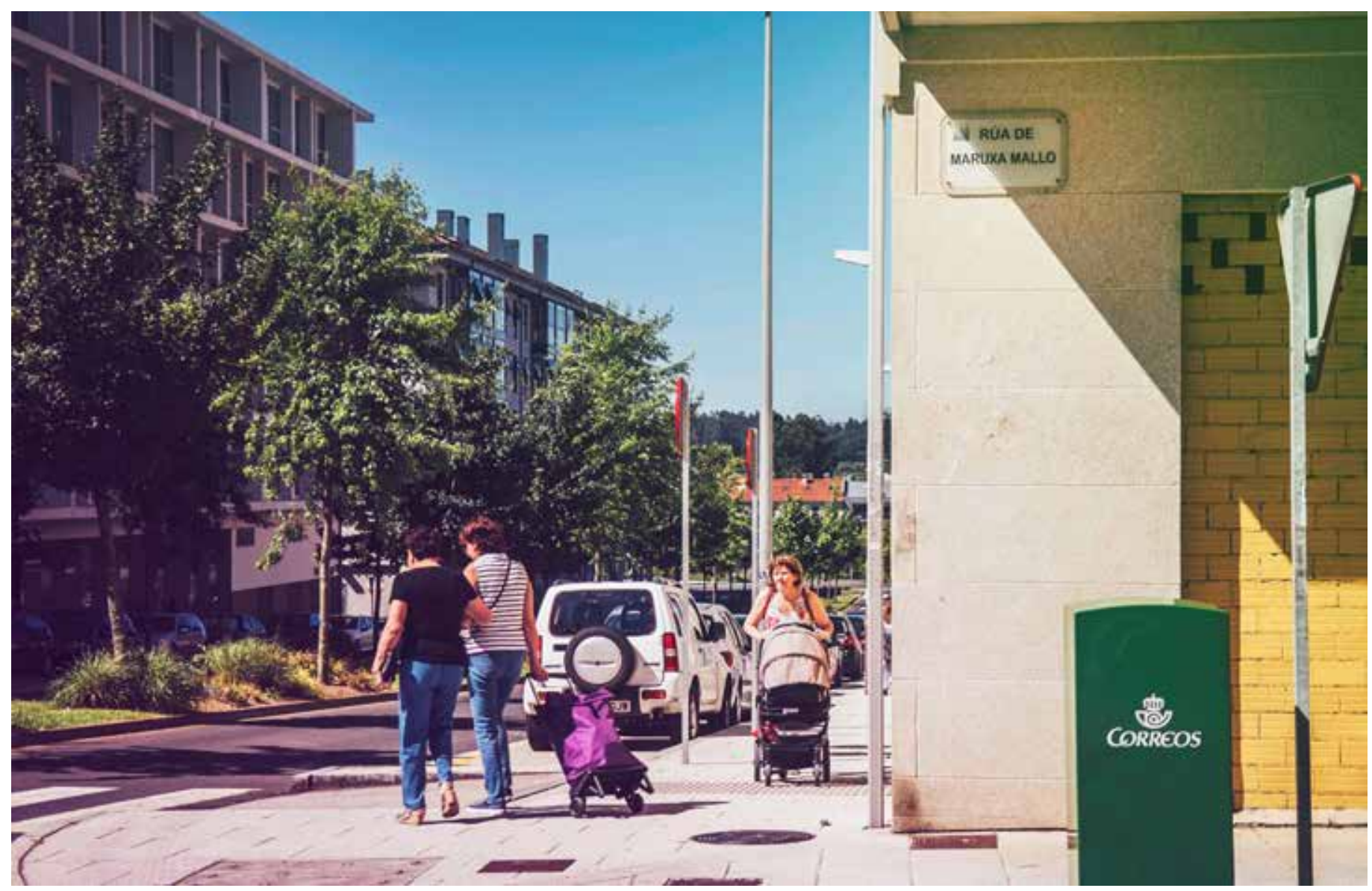

Figure 1: Rúa de Maruxa Mallo / Maruxa Mallo Street. Source: photo by the author, Santiago de Compostela, 2017.
In this context, urban space as ideology, and toponomy as an urban form of power that qualifies territory, is a critical engagement in research that has been developed by political geography (cf. Giraut and Houssay-Holzschuch, 2008a, p. 98), starting in the mid-1980s \& taking place most intensively from the mid-1990s onwards (cf. Rose-Redwood, Alderman \& Azaryahu, 2010, p. 456) through critical place-name studies, stimulating a critical review "of the social and political struggles over spatial inscription and related toponymic practices" (ob. cit., p. 455). Since then, researchers such as Reuben Rose-Redword, Derek H. 
Alderman and Maoz Azaryahu have actively been working on this issue, pointing out how academic tradition "was preoccupied with accumulating and cataloguing the names of places rather than analysing the socio-spatial practice of toponymic inscription itself" (Rose-Redwood, Alderman \& Azaryahu, 2010, p. 456), without taking the authoritarian procedures of place-naming into account. This subsequent reorientation of research has also been noted by other authors such as Duncan Light and Craig Young (2014, cf. p. 436), and has been addressed by Frédéric Giraut and Myriam Houssay-Holzschuch who specifically refer to how "the introduction of 'post-' approaches and issues: Poststructuralist, feminist, and postcolonial theories have been successfully applied to toponymic studies" (Giraut \& Houssay-Holzschuch, 2016, p. 4). All things considering:

The contested politics of place naming are now well documented in the geographical literature, with much of this work focusing on questions of nationalism, (post)colonialism, identity politics, and the spatialization of collective memory (Berg \& Vuolteenaho, 2009; Rose-Redwood, Alderman, \& Azaryahu, 2010). This focus on the politics of place, identity, and naming has gone a long way toward repoliticizing the geographies of toponymic inscription (Rose-Redwood, 2011a, p. 2).

To provide a historical overview, commemorative urban practices were born from the structures of economic and cultural legitimisation that dominated, despite the fact that "traditionally street names were vernacular and designated either geographical orientation and urban function or referred to a certain peculiarity associated with local topography and history" (Azaryahu, 1996, p. 313). The previously cited author, Maoz Azaryahu, in his 1996 article "The Power of Commemorative Street Names", explains that this practice is actually modern since it was created in the eighteenth century in France, in the context of French Revolution, coinciding with the promotion of postal services. Following this, "political, administrative, and urban agendas converged in the formal subjugation of street names in general, and the naming procedure in particular, to official control" (ob. cit., p. 313). That was when the 'geo-locational regime' emerged, where authorities needed "to identify, tax and police their populations and provide them with services (Rose-Redwood, Alderman and Azaryahu, 2010). In this context, naming urban places is one strategy through which urban space is rendered governable (Vuolteenaho \& Berg, 2009), thereby facilitating broader processes of capital accumulation” (Light \& Young, 2014, p. 436). Bearing this in mind:

Place naming is part of a broader history of spatial identification. A genealogy of the latter requires not only a consideration of place naming itself but also how it relates to a whole series of spatial practices such as street and house numbering, the establishment of signage systems, cadastral mapping for the purposes of property management, the creation of postal codes, and other related techniques of spatial inscription (geo-coding) (Rose-Redwood, Alderman \& Azaryahu, 2010, p. 461).

But besides the intention of geo-coding assumed by naming streets, Azaryahu (1996, cf. p. 311) points out that, fundamentally, it also meant transforming urban space into a virtual political setting, suggesting an expression of power which seeks to validate a certain political represen- 
Figure 2: Rúa de Concepción Arenal / Concepción Arenal Street. Source: photo by the author, Santiago de Compostela, 2017. tation and official version of history in the city: "commemorative street names, which are a conventional element of the urban texture, play a special role in naturalizing a prime cultural construct: an hegemonic version of history" (ob. cit., p. 319). This spatial configuration of history has also been named spatial narratives, and they "entail a configuration of locations and time in space" (Azaryahu \& Foote, 2008, p.180). Consequently, and by comparison, "the utilitarian function of a sign is often contrasted with its commemorative dimensions, whereby the former is reduced to the common-sense notion of the need for spatial orientation (denotation) and the latter consists of the more complicated world of symbolic associations (connotation)" (Rose-Redwood, Alderman \& Azaryahu, 2010, p. 460). In the previously cited article "Geographies of toponymic inscription: New directions in critical place-name studies" from 2010, the authors deal with the notion of political semiotics and how it "explores ideology as a cultural form and investigate the socio-political dimension of signs" as it "offers important insights into the study of the relations between toponymy and the politics of cultural signification" (cf. ob. cit., p. 460). Referring again to political power:

Semiotics, or the study of signs, explores the cultural communication of meaning and how messages that are disseminated in the sphere of social communication are encoded and decoded.

Applying a semiotic approach appears to be especially rewarding for the study of commemorative toponyms. The semiotic association between place naming and political power can be traced back throughout the course of history (ob. cit., p. 458).

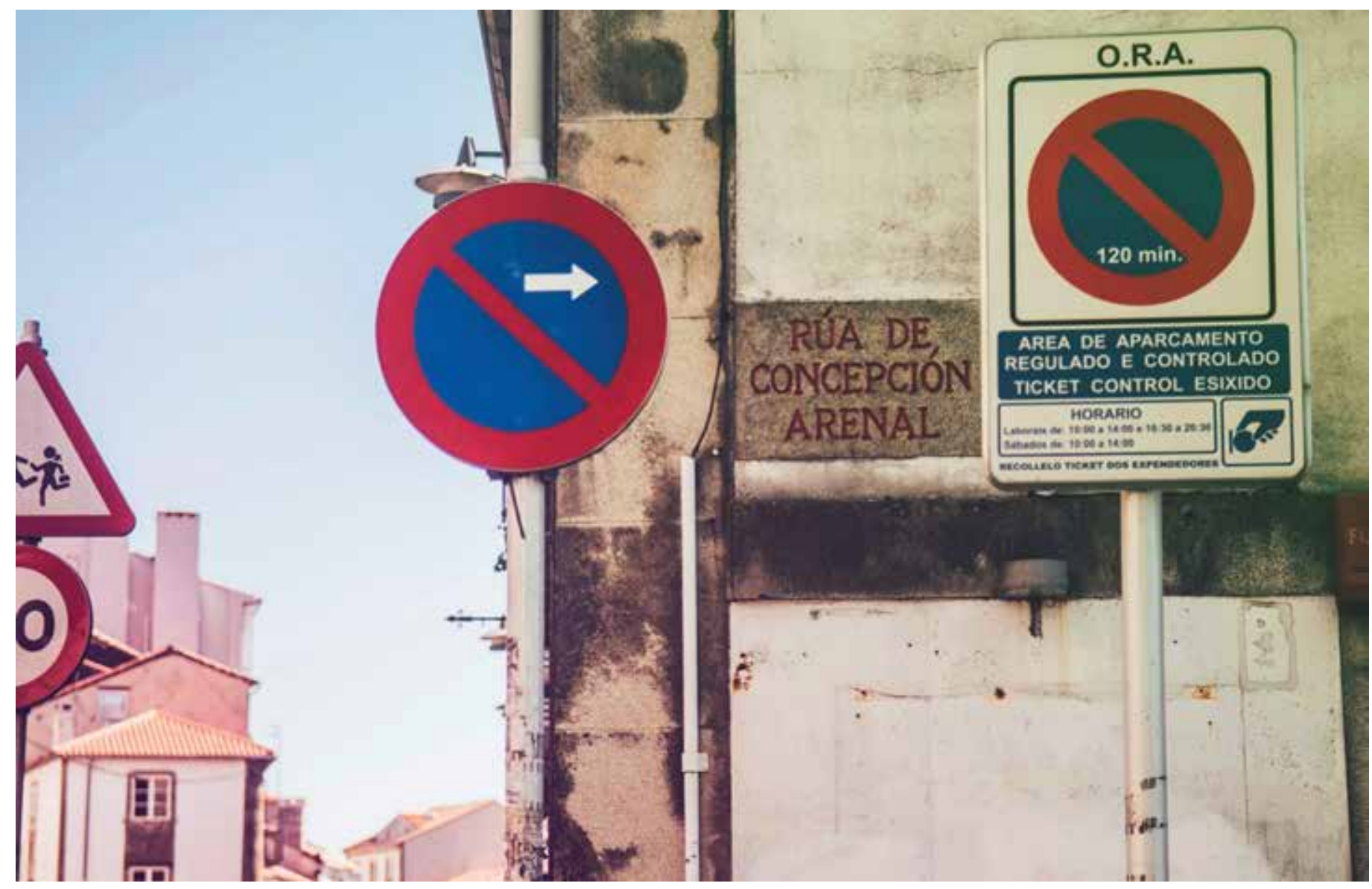


Researcher Edith Kuri Pineda (2013) also stresses the relationship between space and power commemoration, bringing attention to this quality of space as an instrument to build and reproduce power (cf. ob. cit., p. 85). She specifically cites anthropologist Marc Augé and the three elements that shape places (those that are relational, historical and concerned with identity), remarking how place is also identity, social relationality and historicity. ${ }^{2}$ But this process of merging history-relationality-identity and physical environment in an ordered and formal way does not necessarily reflect a social consensus. When faced with social constructed realities that fix, legitimize and naturalize spatial narratives of the elite and dominant groups in public spaces, dissent and opposition based on ethical standards are possible.

Authors Derek H. Alderman and Joshua Inwood (2013) call to analyse place-naming practices in terms of social justice by expressing how:
Figure 3: Rúa das Trece Rosas / Trece Rosas Street. Source: photo by the author, Santiago de Compostela, 2017.
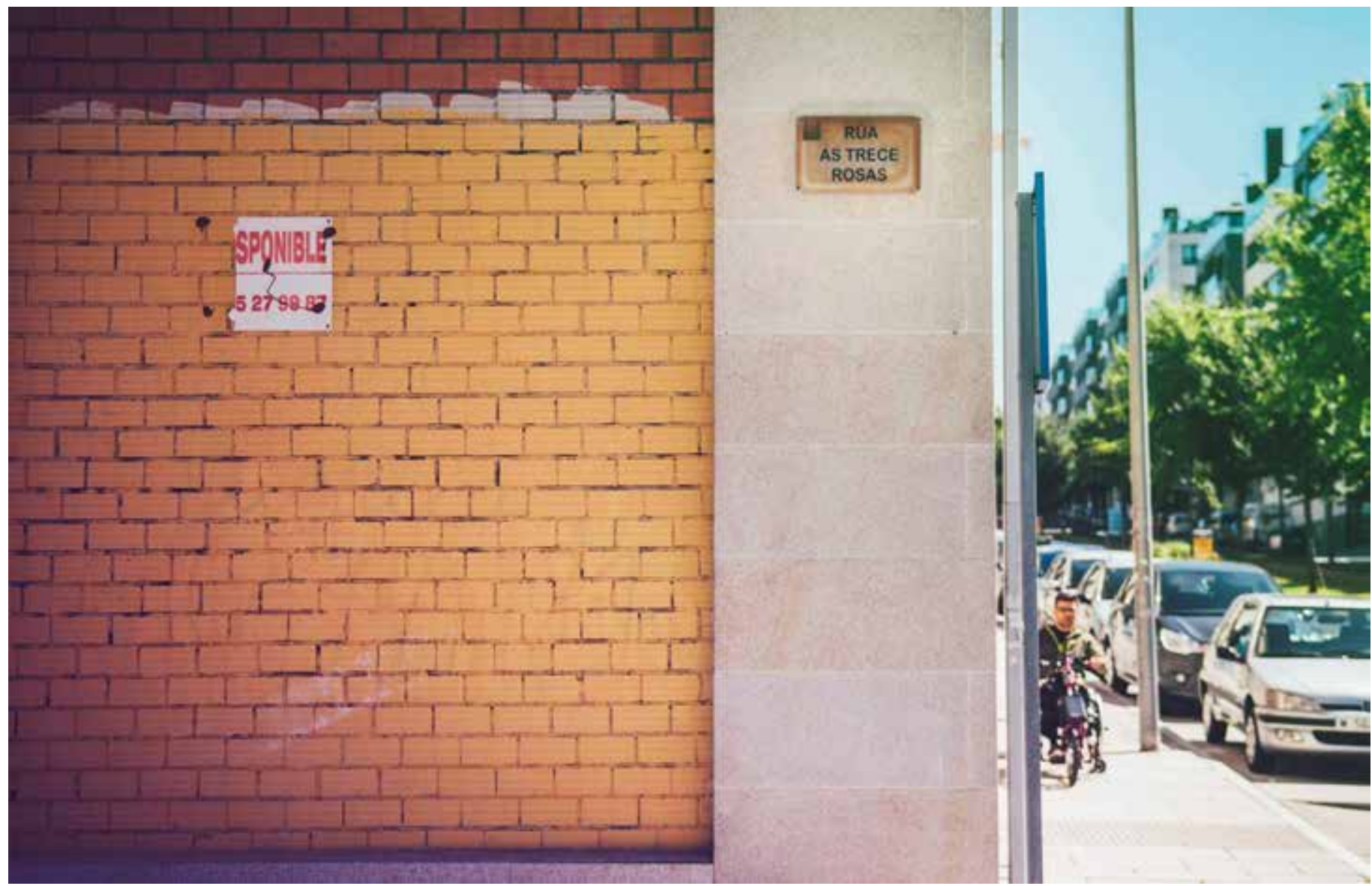

It is especially important to understand how place naming rights and toponymic practices work ideologically to disenfranchise or empower historically marginalized groups as they make claims for public space, political legitimacy and what landscape scholars refer to as the 'politics of belonging' (e.g. Alderman and Modlin forthcoming; Schein, 2009) (ob. cit., p. 213).

\section{Finally:}

Spatial justice recognizes that social, economic, and political injustices are frequently based on and perpetuated through the ways in which we organize, use, and control places and spatial processes. So-
2 Traslated from Spanish by the author from the original text: "Otra puntualización interpretativa pertinente es la formulada por el antropólogo francés Marc Augé, quien sostiene que los lugares están conformados por una tríada de elementos: 1) identificatorios; 2) relacionales y 3) históricos (Augé, 2008). El lugar es, pues, identidad, relacionalidad social e historicidad" (Kuri Pineda, pp. 89-90). 
cial life is inherently territorialized and any meaningful effort to create social justice must address the geographic order that constitutes and shapes social inequalities and unfair decision-making processes (Bromberg et al., 2007: 2)" (ob. cit., p. 219).

\section{Towards Commemorative Urban Practices from Situated Perspectives}

Urban anthroponymy is a main exponent of collective memory in public space. As it was previously outlined, naming urban elements is a widespread political decision-making process which seeks to commemorate and legitimise a hegemonic understanding of history through the spatial narratives of power. Streets' toponomy (odonyms), together with monuments or plaques and the naming of singular or institutional buildings, are part of a validation system based on the enhancement of a human archetype with a certain social status that ultimately embodied in a tangible expression: visible anthroponomic inscriptions (cf. Giraut \& Houssay-Holzschuch, 2017, p. 4).

For centuries, from the established power bodies, decision-making institutions' procedures have established a methodology of recognition which is both biased and skewed, relying on an androcentric process that has implied exclusion mechanisms (gate-keepers). This favoured the interests of a privileged minority, penalizing, limiting and constraining the inclusion and visibility of a wide and plural range of human beings, mainly women (as they make up approximately $50 \%$ of the population), but not exclusively. Thus, space is not only an instrument of power domination, but also of political tension between different social actors (cf. Kuri Pineda, 2013, p. 87). In terms of spatial justice, street toponomy has been a field of struggle for legitimacy from racial and ethnic perspectives, with the goal of reshaping urban space identity (cf. Alderman \& Inwood, 2013, p. 215), to address gender, class and postcolonialism concerns.

A consideration of distributive justice prompts us to consider how the toponymic landscape should be reconstructed in ways that reflect and give voice to previously suppressed histories and identities. Exactly how many of our schools, streets, bridges, stadiums, and parks are named for minorities? A concern with distribution also draws attention to an analysis of the intraurban spatial context and the degree to which toponyms work, depending on their location, to marginalize or raise the perceived public legitimacy of subordinate groups. What is the 'place' of certain named public spaces in relation to a city's array of race-, gender-, and class-based spatial distributions? Without serious consideration of this question, places named for marginalized groups could actually work to alienate and further segregate these groups (Alderman, 2002a). As Raento and Watson (2000, p. 728) recognize, 'Naming and re-naming are strategies of power, and location matters, because this power is only truly exercised when it is "seen" in the appropriate place' (Rose-Redwood, Alderman \& Azaryahu, 2010, p. 465).

In this light, scholars have been using the metaphor of cultural arena as a way of focusing "on the capacity of place names to serve as sites of contest, debate, and negotiation as social groups compete for the right to name" (ob. cit., 2010, p. 462): 
One possible way of understanding the socially constructed and contestable nature of place naming. An arena approach recognizes place naming as part of the broader production of public space and the capacity of naming — as a place-making process - to serve as sites of contest, debate, and negotiation. Social groups and actors within those groups, with varying goals and levels of power and resources, compete for the right to name the landscape and cast legitimacy on their political vision, cultural history, and identity (Alderman 2002). The arena metaphor recognizes the highly public and performative nature of debates over toponymic practice as people seek to influence collective decisions or policies and justify their claims (Alderman \& Inwood, 2013, p. 215).

Thus, toponymic inscription is understood not only as a product of established power, but a place where rising power has a chance to surface. Traditionally excluded actors can then become active ones "regarding decisions related to the space they inhabit and not merely spectators" (Shoval, 2013, p. 624), claiming their right to the city and calling into question the political innocence (Rose-Redwood, 2011b, p. 34), impartiality, neutrality or accidentally/apolitical nature of naming processes. Since considering toponyms as "isolated linguistic objects" (Tucker and Rose-Redwood, 2015, p. 197) has the problem of confining naming processes "to the supposed qualities of the toponym itself while ignoring the broader set of political processes at work in the production of toponymic landscapes" (Rose-Redwood, 2011a, p. 3), while others "are overlooked or marginalized" (Light \& Young, 2014, p. 436).

Newer toponymic approaches stress the cultural politics of naming, paying close attention to who controls the naming process (and conversely who does not) as well as the cultural and political world views that are given voice (and made silent) through the place name landscape. Place names are more than innocent spatial references or passive artefacts; they are embedded in social power relations and struggles over the identities of places and people (Berg \& Vuolteenaho 2009; Kearns \& Berg 2002) (Alderman \& Inwood, 2013, p. 212).

Feminist theory has focused the analysis on placing historically marginalized social groups at the core. Specifically, systematic exclusion of women from social recognition has its roots in the gendered segregation of spheres, specifically the private/public dichotomy. Private and domestic spaces, where reproductive and care work have taken place, were where women were historically confined, while men actively participated in public life. It is precisely in this public domain that social values that seen as traditional take place: productive work, politics, culture, etc. (cf. Guerra Palmero, 1999, p. 47).

According to the article "Women, Identity and Public Space" written by María José Guerra Palmero, since the exclusion of women from full citizenship during the French Revolution as(they were considered inherently passive and submissive, suitably home-oriented, the subtext of the gender of the citizens' role has been masculine, and the consequences of being a public woman were only shame and mock (cf. ob. cit., p. 51). The access of women to public spaces was key in order to achieve social recognition, but during the Age of Enlightenment, influential thinkers such as Jean-Jacques Rosseau reinforced biological determination theories. As a result, masculine norms of public and pri- 
vate were the ones authorized and legitimized to build commemoration processes, devaluing women's contributions by classifying them as not worth considering. This supposed universal objectivity and neutrality of traditionally dominant groups' spatial narratives are once more highlighted in this article where the author concludes how:

The discourse — which is 'masculine' in the sense of the only ones legitimated to speak out are men - would be covered of authority, would be identified with the truth, the rationality and the objectivity; only they will get the credibility and the recognition to speak in the name of general interest. Women's contributions will be devalued and their opinions always 'subjective'. The objectivity is masculine ${ }^{3}$ (Guerra Palmero, 1999, pp. 52-53).

To ensure ethical quality in the discourses and paradigms of the recognition methodology, gender and feminist studies have broadly discussed this supposed universal neutrality and objectivity, problematizing its political innocence. From that critical engagement, feminist approaches point out large differences in the recognition of non-privileged social actors' contributions, which remain in force as a source of social inequality. In order to overcome the biased doctrine of objectivity as a commonly presumed truth, situated perspectives arise as an opportunity for a feminist-sensitive contestation.

According to Donna Haraway (1988), "Feminist objectivity means quite simple situated knowledges" (p. 581). The influential author claims that we must transform objectivity debates since "History is a story" (ob. cit., p. 577), an allegory created from Western culture that new critical theories seek to transform. A central idea emerges in her words: "Feminists don't need a doctrine of objectivity that promises transcendence, a theory that loses track of its mediations just where someone might be held responsible for something, and unlimited instrumental power. We don't want a theory of innocent powers to represent the world" (ob. cit., p. 579), but what we need is an:

An earth-wide network of connections, including the ability partially to translate knowledge's among very different -and power-differentiatedcommunities. We need the power of modern critical theories of how meanings and bodies get made, not in order to deny meanings and bodies, but in order to build meanings and bodies that have a chance for life (Haraway, 1988, p. 580).

3 Translated from Spanish by the author from the original text "El discurso —que es «masculino», en el sentido que los únicos legitimados para tomar la palabra son los hombres- se cubrirá de autoridad, se identificará con la verdad, la razón y la objetividad: sólo ellos obtendrán la credibilidad y el reconocimiento para hablar por boca del interés general. Las contribuciones de las mujeres siempre serán devaluadas y sus opiniones siempre «subjetivas» La objetividad es masculina".

4 Translated from Spanish by the author from the original text "justamente en el espacio público —en tanto territorio de la pluralidad cultural, política y social- se entablan pugnas políticas y simbólicas encaminadas a plasmar en él una(s) visión(es) del pasado”.

\section{Collective (Spatial) Narratives as a Living Social Construction}

In contexts of social and political change, -which can be understood to be where effective equality is being built, the role of collective memory is key given that "it is precisely in public space -as a territory of cultural, political and social plurality- [where] political and symbolic struggles are settled aiming to depict a past view(s)" (Kuri Pineda, 2017, p. 27).

Edith E. Kuri Pineda develops this idea in her article "The Social Construction of Memory in the Space: A Sociological Approach": "speaking about memory means to allude to a social process where historicity, time, space, social relationships, power, subjectivity, social practices, conflict and, of course, transformation and permanence, is condensed" ${ }^{5}$ (ob. cit., p. 11). Here, collective memory is conceived as 
a living social construction, created for a specific purpose, and yet, it is also a place of political confrontation to dispute legitimation and supremacies: (cf. ob. cit., p. 10) once again, the cultural arena. Hence, as previous authors have empathised, public space would be a social construction: "an historical construction that has different levels, like the urban, the cultural, the symbolic, the legal and de political one" ${ }^{6}$ (ob. cit., p. 21).

In the same vein, author Irina Yanushkevich (2014) discusses in her

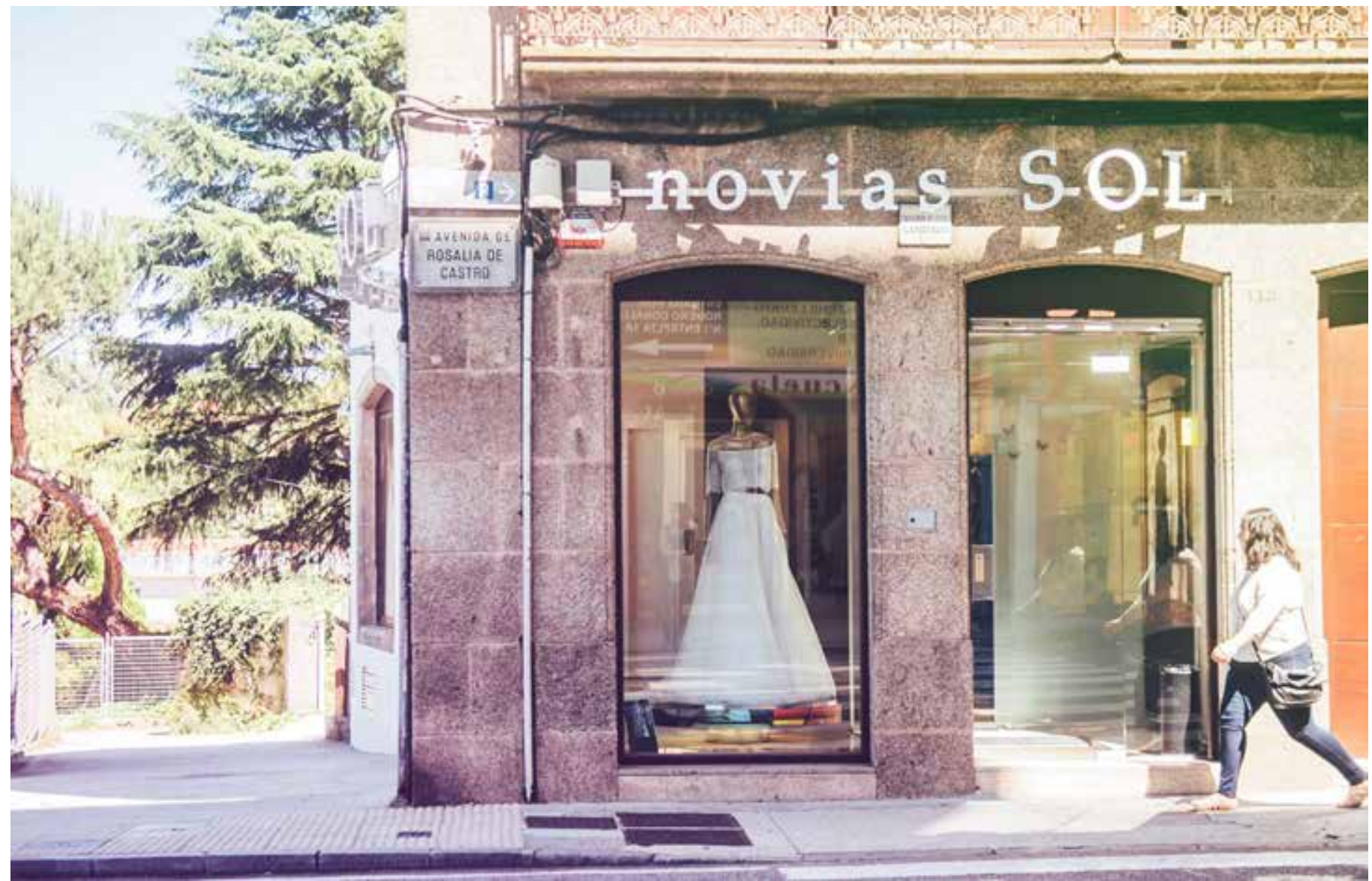

article "Semiotics of Social Memory in Urban Space: The Case of Volgograd (Stalingrad)" more in detail that "social memory as a kind of collective memory deals with the knowledge of the past and the present, about historical events and historical personalities, and includes emotional experience" (p. 44). The researcher adds the idea that emotional experiences can keep up group identities that do not necessarily have to coincide with official established identities, emerges from social construction because "the way in which the past is called up depends on the power of the group which creates the memory of its own" (ob. cit., p. 44). At that point, "social memory becomes one of the key elements determining the present state-of-affairs of the society and actively shaping its future" (ob. cit., p. 49).

Although power would be consolidated itself through the link between memory and space, marking territory, objectifying itself and giving symbolic dimension to physical space -as earlier pointed out-, memory establishes interconnections between past and present, but also the future, joining experience with forthcoming horizons. It is precisely this symbolic dimension of public space which makes its resignification
Figure 4: Avenida de Rosalía de Castro / Rosalia de Castro Avenue. Source: photo by the author, Santiago de Compostela, 2017.

5 Translated from Spanish by the author from the original text "Hablar de la memoria supone aludir a un proceso social en el que se condensa historicidad, tiempo, espacio, relaciones sociales, poder, subjetividad, prácticas sociales, conflicto y, por supuesto, transformación y permanencia."

6 Translated from Spanish by the author from the original text "El espacio público es una construcción histórica que cuenta con diversos planos, como el urbanístico, el cultural, el simbólico, el legal y el político." 
from a feminist theory of situated perspectives committed to the pursuit of spatial justice possible:

The vision of the past that is made socially important through place naming is not simply a matter of 'political correctness', as suggested by many opponents, but vital to achieving fairness in cultural and political representation and preventing the symbolic annihilation of marginalized social groups and their historical identities (Rose-Redwood, Alderman \& Azaryahu, 2010, p. 465).

In the article "Toward a Geography of Memory: Geographical Dimensions of Public Memory and Commemoration“, Kenneth E. Foote and Maoz Azaryahu (2007) explain how recent studies "have also underscored the point that the geography of public memory is dynamic: New commemorative features are added while others, abruptly or gradually, disappear. Monuments are re-interpreted and their social and political relevance is reformulated according to contemporary priorities and sensitivities" (p. 6). In this dynamic, changes in toponomy as a strategy of power to redefine its political dimension refer not only to neotoponimy - "allocating a name to a new place, e.g., a new street, dam, airport, or even an administrative jurisdiction, such as a province or municipality“ (Giraut \& Houssay-Holzschuch, 2016, p. 4) -, but also to renaming (replacing toponyms), since "naming territory is a founding political action, renaming also remain politically relevant"7 (Giraut \& Houssay-Holzschuch, 2008a, p. 97).

When continuity is desired, a possible solution is the commemorative naming of public spaces in newly built neighbourhoods to compensate for alleged or real past commemorative deficiencies.

Another option is to rename existing landmarks, streets, and other places. This phenomenon figures prominently in periods of regime change and revolutionary transformation, when 'renaming the past' is a measure of officially promoted historical revision. Together with pulling down monuments, an ideologically motivated rewriting of city-texts belongs to a 'semiotic revolution' that signifies discontinuities in political history (Rose-Redwood, Alderman \& Azaryahu, 2010, p. 460).

In this regard, Derek H. Alderman and Joshua Inwood, (2013) turning to the issue of spatial justice previously noted, focus on street naming with regards to the right to participate and the right to appropriate (cf. p. 4) stressing its key importance of the politics of belonging in decisionmaking processes in urban space (ob. cit., p. 14). And as Frédéric Giraut and Myriam Houssay-Holzschuch (2008a) have pointed out "in the act of appropriation that transform space in territory, naming and renaming remain essential" ${ }^{8}$ (p. 104).

7 Translated from French by the author from the original quote: "Nommer le territoire est un acte politique fondateur; le renommer est tout aussi politiquement significant".

8 Translated from French by the author from the original quote: "Dans l'acte d'appropriation qui érige l'espace en territoire, nommer et renommer restent essentiels".
In summary, critical place name scholars recognize the central and contested place that toponyms hold in people's lives and their struggles over identity and rights, understood here as not only the legal authority to name a place but also the broader rights of people to participate in the production of place and to have their cultural identities and histories recognized publicly (Alderman \& Inwood, 2013, p. 212).

This idea of transforming established standards by participation, was pointed out by notable authors such as Dolores Hayden (1997). Women's active participation in decision-making processes can encour- 


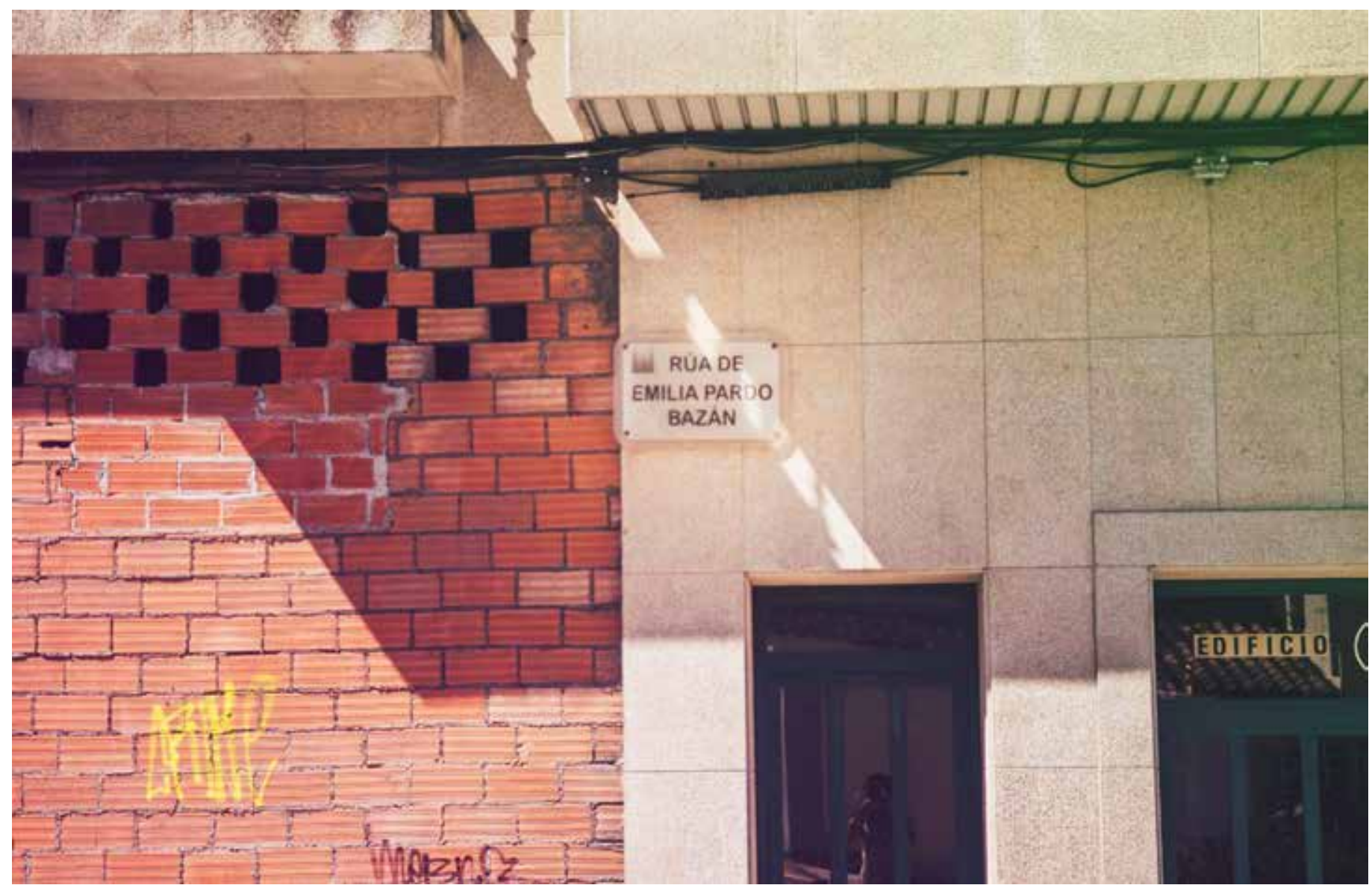

age a more diverse recognition of collective memory in public space (cf. ob. cit, p. 7).

In this context, situated perspectives must be empathized, as a method to incorporated traditionally neglected narratives into the construction of collective memory in our cities.

\section{The Case of Santiago de Compostela Urban Toponymy}

\section{Methodology}

Following the theoretical basis and background from the problem of the subject as a starting point for the research, I will address the case of Santiago de Compostela through the study of its urban toponomy from a gender-based perspective.

Santiago de Compostela is the capital of Galicia, in the northwest of Spain, and it has a population over one hundred thousand inhabitants, which almost doubles when including the metropolitan area. Santiago is an administrative capital, but also a cultural one: the historical importance of its ancient European pilgrimage route ( $\mathrm{El} \mathrm{Cami-}$ no), its historic university and its monumental city core made it worthy of being named a World Heritage Site by UNESCO. For these and many other reasons, several initiatives from the City Council seek to involve citizens in the construction of a female-friendly city, including at a symbolic level. In this light, the study of urban toponomy is a tool that can help to create a more inclusive city, and this is the purpose of this investigation
Figure 5: Rúa de Emilia Pardo Bazán / Emilia Pardo Bazán Street. Source: photo by the author, Santiago de Compostela, 2017. 


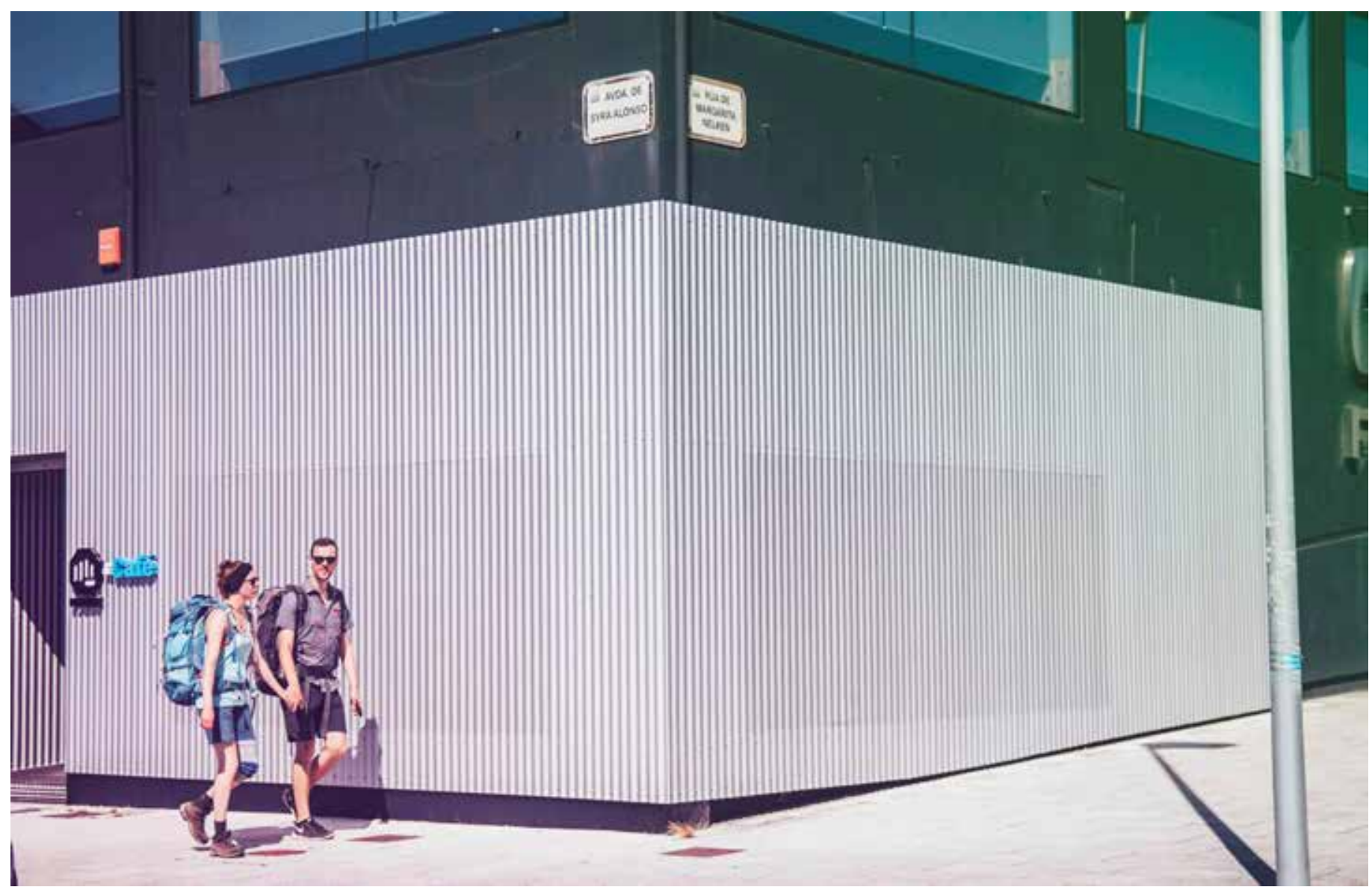

Figure 6: Avenida de Syra Alonso, rúa de Margarita Nelken / Syra Alonso Avenue, Margarita Nelken Street. Source: photo by the author, Santiago de Compostela, 2017.
Accordingly, in the analysis of Santiago de Compostela commemorative urban practices through the way its streets are named, we will focus on a quantitative research of its urban anthroponymy in order to compare and discuss the results.

Quantitative analysis was based on data collected from official sources (Concello de Santiago de Compostela, 2016), provided by Santiago de Compostela City Council. The study includes the following feminine and masculine anthroponymies: official names and surnames of historical civil figures (mainly intellectuals and professionals), military figures, religious figures (ecclesiastical or canonized), aristocrats and unofficial examples such as trades and professions and others (generics, anonymous, etc.). It also seeks to determine a different hierarchy distinction of the streets: avenue, square/park/garden and street/road/crossing and others (including slopes, stairs, quarter, canton, alley, route and driveway). Categories were established by those that were more representative and predominant but also by determining a different symbolic hierarchy and function in mobility patterns in the city. Finally, and to clarify, toponyms referring to the etymology of other locations were not considered, despite also alluding to religious figures (such as "Santiago de Chile", among others), based on the understanding that the purpose was to mention a geographical origin rather than a historical character.

On another level, we used secondary data sources of information from other cities cases to establish comparisons. On one hand, data from Galicia's most important cities (Pontevedra, Ourense, Lugo and A Coruña) was based on the only article found by Patricia Arias Chachero published in 2007 "Mulleres na rúa: sobre toponimia urbana". Despite not being considered a scientific approach to the problem, it is both useful and interesting due to its pioneering approach to Galician 
reality. On the other hand, concerning other major cities from Spain, data released on the internet and featured in the media over the last few years was considered a useful tool as an approach to creating a general framework for the comparative analysis.

\section{Urban Anthroponomy of Santiago de Compostela}

Nomenclator database supplied by the municipality displays a total of 1,059 different street names of Santiago de Compostela. Of these, 383 are anthroponyms and commemorate human figures, representing a percentage of $36.2 \%$ of the whole.

The vast majority of the 383 anthroponyms points to masculine gender: a total of 287 compared to ninety-seven feminine ones. Table 1 shows how this pronounced unbalance between figures is also reflected in percentages: of all individuals represented $74.7 \%$ are masculine characters and only $25.3 \%$ are feminine ones, that is to say, we can find three men of every four figures - but only one woman. It is important to note that one third of existing feminine toponyms were added in 2007, following a relatively recent motion from the Santiago de Compostela City Council which sought to name roads in new housing complexes. ${ }^{9}$ Therefore, these numbers were far more alarming some years ago, when the city only had sixty-five thoroughfares named after women.

Regarding the characters' profiles, data shows significant differences between social groups. The analysis processes revealed distinct social categories: historical civil figures (where we can find intellectuals, professionals, bourgeois or even victims), military figures (which have different political connotation), religious figures (including people who embraced ecclesiastical life and canonized figures), aristocrats (members of royal families and the nobility such as dukes, marquis, etc.), trades and professions (generic names referring to working class people as marineiras ("fisherwomen") or canteiros ("masons")) and others (including those difficult to classify).

\begin{tabular}{|l|c|c|c|c|}
\hline \multirow{2}{*}{ Profile } & \multicolumn{2}{|c|}{ Masculine } & \multicolumn{2}{c|}{ Feminine } \\
\cline { 2 - 5 } & $\mathrm{n}^{\circ}$ & $\%$ & $\mathrm{n}^{\circ}$ & $\%$ \\
\hline Civil figures & 179 & $61.3 \%$ & 37 & $38.1 \%$ \\
\hline Military figures & 10 & $3.5 \%$ & 0 & $0 \%$ \\
\hline Religious figures & 82 & $28.6 \%$ & 50 & $51.5 \%$ \\
\hline Aristocrats & 7 & $2.4 \%$ & 3 & $3.1 \%$ \\
\hline Generic professions & 5 & $1.7 \%$ & 1 & $1.1 \%$ \\
\hline Others & 7 & $2.4 \%$ & 6 & $6.2 \%$ \\
\hline TOTAL & 287 & $100 \%$ & 97 & $100 \%$ \\
\hline
\end{tabular}

Data included in Table 1 shows a wide gap between selected profiles to commemorate public urban spaces based on gender. It must be noted that social profile determines the main and official cause of ultimate tribute of the figure. Whilst men are mainly intellectuals, professionals and economic and political power representatives (civil figures, $61.3 \%$ ), women are principally saints and virgins (religious figures, $51.5 \%$ ). Furthermore, in the first category, if we compare masculine and feminine civil occupations, it becomes evident that there is a dis-
Table 1: Quantity and percentages of figures commemorated in Santiago de Compostela urban anthroponyms by gender and social profile. Source: prepared by the author based on data supplied by Santiago de Compostela City Council, 2016. 
parity in the type of work performed: males had more than thirty-six different and varied occupations, while females only had seventeen, indicating that almost the all of the latter were explicitly added in 2007.

In this sense, among the civil figures, we can find men related to powerful positions as politicians, businessmen, bankers, lawyers or judges; renowned intellectuals such as writers, philologists, poets, astronomers, scientists, mathematicians, philosophers, physicians, chemists, pharmacists, cartoonists, surgeons, doctors, historiographers, journalists, painters, architects, sculptors, inventors, archaeologists, political scientists, economists, professors, geologists, botanists, veterinarians or songwriters. This is evidence of a heterogeneous sample that includes even troubadours, benefactors or unionists.

Nevertheless, female civil figures are more related to the art world (filmmaker, dancer, actress, painter, drawer and musician), as well as teachers, academics, activists, writers, politicians, scientists, unionists and philosophers. Figures 1 to 9 are just one small example of this fact.

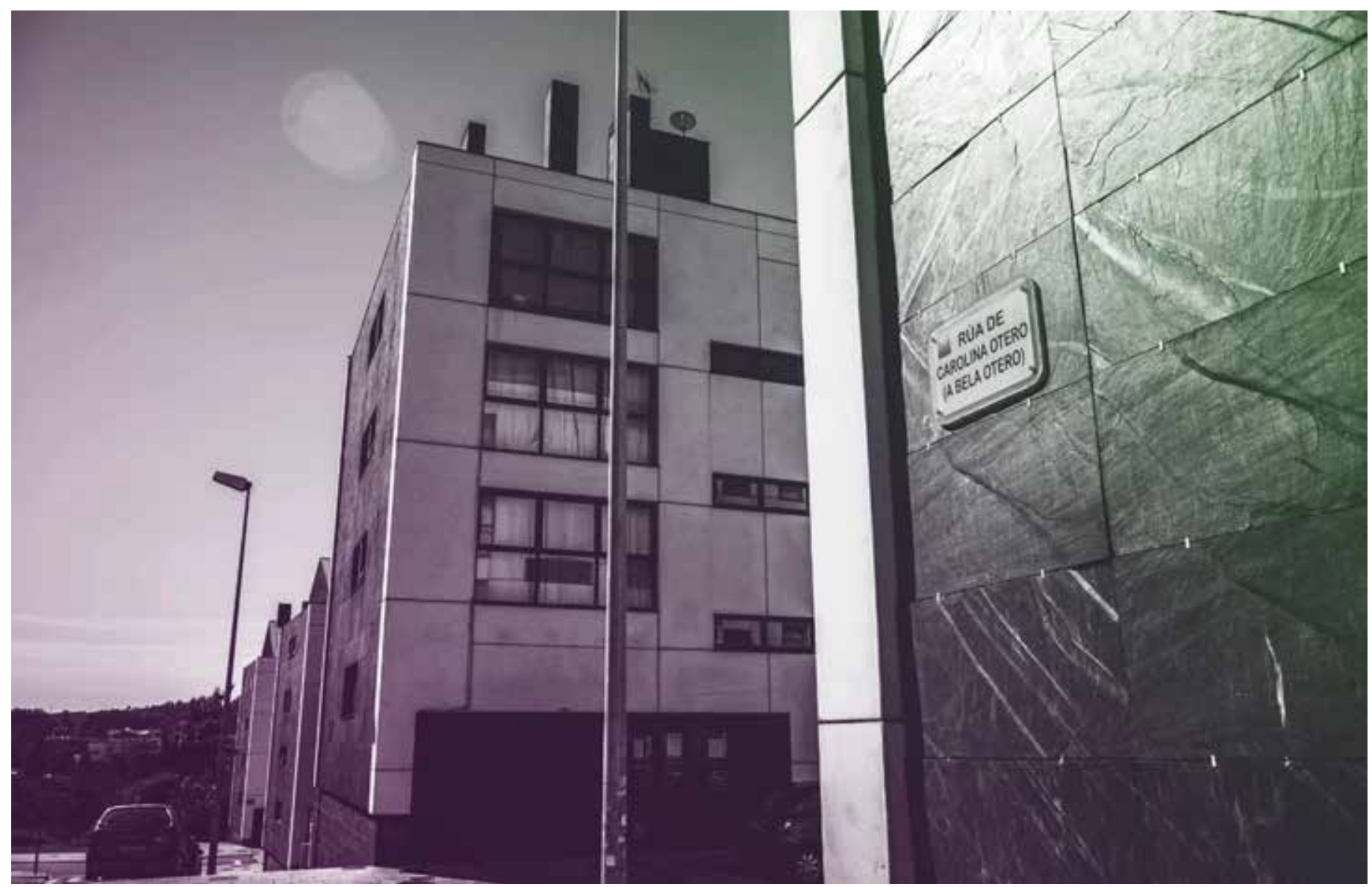

Figure 7: Rúa de Carolina Otero (A Bela Oterol / Carolina Otero Street. Source: photo by the author, Santiago de Compostela, 2017.
Likewise, the data exposes the lack of military women compared to the ten masculine toponyms. However, these figures stand in contrast to the large amount of feminine religious figures, which form more than half of the total feminine toponyms $(51.5 \%)$, which is in stark contrast to the low number of masculine religious figures' representation $(28.6 \%)$. Therefore, women are mainly canonized characters but not ecclesiastic figures, which means santas (saints), virxe (virgins), nosa señora (our lady of), fillas (daughters of), irmás (sisters of), or biblical characters, reaffirming their traditional subaltern gender role reinforced by the Catholic religion over centuries and being an enduring expression of what Galician linguistic experts have identified as "the great influence permanently exerted by ecclesiastical institutions as a major shap- 
ing force of Galician society" since the Middle Ages ${ }^{10}$ (Boullón Agrelo \& Tato Plaza, 1998-1999, p. 16).

\section{Urban Anthroponymy of Santiago de Compostela and Thoroughfare Hierarchy}

In this study based on the quantity of anthroponyms focusing on their gender in urban public spaces in Santiago de Compostela, there are also disparities concerning the symbolic hierarchy of each element.

In the 1,059 urban anthroponyms considered, we can find a variety of different types of public thoroughfares, from the most common such as avenues, squares, parks, gardens, streets, walkways, roads or crossings to the least common such as traffic rings, slopes, hills, stairs, quarters, cantons, alleys, routes or driveways.

From the 383 street names referring to human figures, selected categories were: avenue, square/park/garden and street/road/crossing and others (including slopes, stairs, quarter, canton, alley, route and driveway). The main criterion has been to highlight those that are more representative and predominant, and to distinguish different mobility patterns, their influence and symbolic hierarchy.

\begin{tabular}{|l|c|c|c|c|}
\hline \multirow{2}{*}{ Typology } & \multicolumn{2}{|c|}{ Masculine } & \multicolumn{2}{c|}{ Feminine } \\
\cline { 2 - 5 } & n. ${ }^{\circ}$ & $\%$ & n. $^{\circ}$ & $\%$ \\
\hline Avenue & 37 & $12.9 \%$ & 4 & $4.1 \%$ \\
\hline Square/Park/Garden & 19 & $6.6 \%$ & 4 & $4.1 \%$ \\
\hline Street/road/crossing & 217 & $75.6 \%$ & 81 & $83.5 \%$ \\
\hline Others & 14 & $4.9 \%$ & 8 & $8.3 \%$ \\
\hline TOTAL & 287 & $100 \%$ & 97 & $100 \%$ \\
\hline
\end{tabular}

The data displayed in Table 2 shows how hierarchy implies a gender bias in name selection. In a symbolic order, those considered more important, such as avenues for example, are mostly named after masculine figures. Specifically, avenues are named after men three times more than after women (12.9\% against $4.1 \%)$. In addition, and as a direct consequence, we can conclude that feminine toponyms are principally found on secondary streets (83.5\% against $75.6 \%)$, which is likely to influence their lack of central location in the city. For this reason, spatial distribution and the central or periphery nature of elements, remains of interest for future research.

\section{Comparing the case of Compostela with other major Galician cities}

The differences in the Santiago de Compostela case study, while presenting a pronounced unbalanced situation, are not as severe as in other major cities of the region, where data outlines a significant situation of inequality: we counted ninety-seven feminine toponyms in Compostela (Galicia's capital city) which form $9.2 \%$ of the total 1,059 names, but according to the only article found, written by Patricia Arias Chachero in 2007, this percentage is much lower in other provincial capitals such as Pontevedra with seventeen feminine toponyms (3.9\%), Ourense with more than forty (4.5\%) or A Coruña (6\%) (cf. ob. cit., pp. 46-49).
Table 2: Quantity and percentages of figures commemorated in Santiago de Compostela urban toponyms by gender and thoroughfare typology. Source: prepared by the author on the basis of data supplied by Santiago de Compostela City Council, 2016.
10 Galician academics Ana IsaBel Boullón Agrelo and Fernando R. Tato Plaza (1998-1999) have conducted essential research on this issue: "in order to understand the situation of Galician personal names in the transition from the Middle Ages to modern times, we must bear in mind one essential factor: the introduction of Spanish in Galicia" during the 'Dark Centuries'; then "the introduction of proper names in registers, ecclesiastic at first and the civil, coincided with the onset of the virtually systematic castilianization of names, and part of the surnames" (1998-1999:29). They conclude how "the most important development of this period for Galician personal names is the creation of a closed repertoire of names composed almost exclusively of saints' names" (p. 30). 
On one hand, it is necessary to note that a third of feminine toponyms were added in 2007 , and it is likely that before that year, data would have been comparable to the other Galician cities (i.e. an average between $4 \%$ and $6 \%$ ). On the other hand, $27.1 \%$ of masculine toponyms compared with $9.2 \%$ of a total of 1,059 names, is a symbolic statement, only partially representing the plurality and diversity of the city. Considering the rest of the region, these percentages are even amplified in some cases as Pontevedra, where $43.2 \%$ of urban public spaces are named after men (cf. Arias Chachero, 2007, pp. 46-49).

\section{Comparing the Compostela case with other major Spanish cities}

To enable comparison between Compostela and other Spanish major cities, data was compiled from accessible information, nearly all of which was released in the press over the last few years. It emerged that, in Madrid, the number of masculine urban anthroponyms is three times greater than the number of feminine anthroponyms. Nonetheless, $21 \%$ of more than 9,000 streets of this large city are named after women, a percentage considerably higher than the $9.2 \%$ in Santiago de Compostela. The proportion of female anthroponyms is similar to that of Barcelona (19\%). Valencia, with $10 \%$, is an example of a situation of severe imbalance resembling Compostela (Llaneras \& Pérez Colomé, 2017).

In Madrid, as in Santiago de Compostela, the main reason that motivates naming public spaces in honour of women is religious, with this type making up $83 \%$ of the total feminine anthroponyms. This number is higher than the $51.5 \%$ in Compostela, which perhaps explains the fact that there are more female names i. e. because there are more saints. At the same time, male anthroponyms originate from a wide variety of different professions, while "the only occupation reflected on a plaque of two women is 'teacher'” (Llaneras \& Pérez Colomé, 2017).

As in Compostela, Barcelona City Council have also promoted naming streets after women since 1996, gradually increasing from original 27 streets $(7 \%)$ to 97, as quantified in 2010 (Sánchez, 2016).

In Córdoba, of the 4,403 names, scarcely 141 thoroughfares remember feminine figures $(3.2 \%)$, despite including a high number of religious figures (Eldestein, 2017). In Palencia, for example, the gap is noticeable including 216 masculine names against 45 feminine examples (De la Cruz, n.d.), resulting in $83 \%$ for the former compared with $17 \%$ for the latter. Moreover, as in Compostela, only streets are named after women, with practically no evidence of female names for avenues or squares.

\section{Concluding Remarks}

\section{Compostela, a Case Study in a Generalized Inequality Context}

Data shows that Santiago de Compostela urban anthroponyms reveal a substantial gender gap, with the number of celebrated masculine figures being triple the number of feminine ones $(9.2 \%$ against $27.1 \%)$. Moreover, the vast majority of feminine urban toponyms referred to are religious figures (but not historical ecclesiastic charac- 
ters related to power institutions). Data suggests that they are mostly saints, virgins, etc. This traditional female role category correlates, in a traditionally Catholic state like Spain, to the influence, promotion and legitimization of patriarchal power of the Catholic Church since the Middle Ages: a woman must be devout, submissive and passive. The authorized version of women's history in the city is that saints are the ones to venerate.

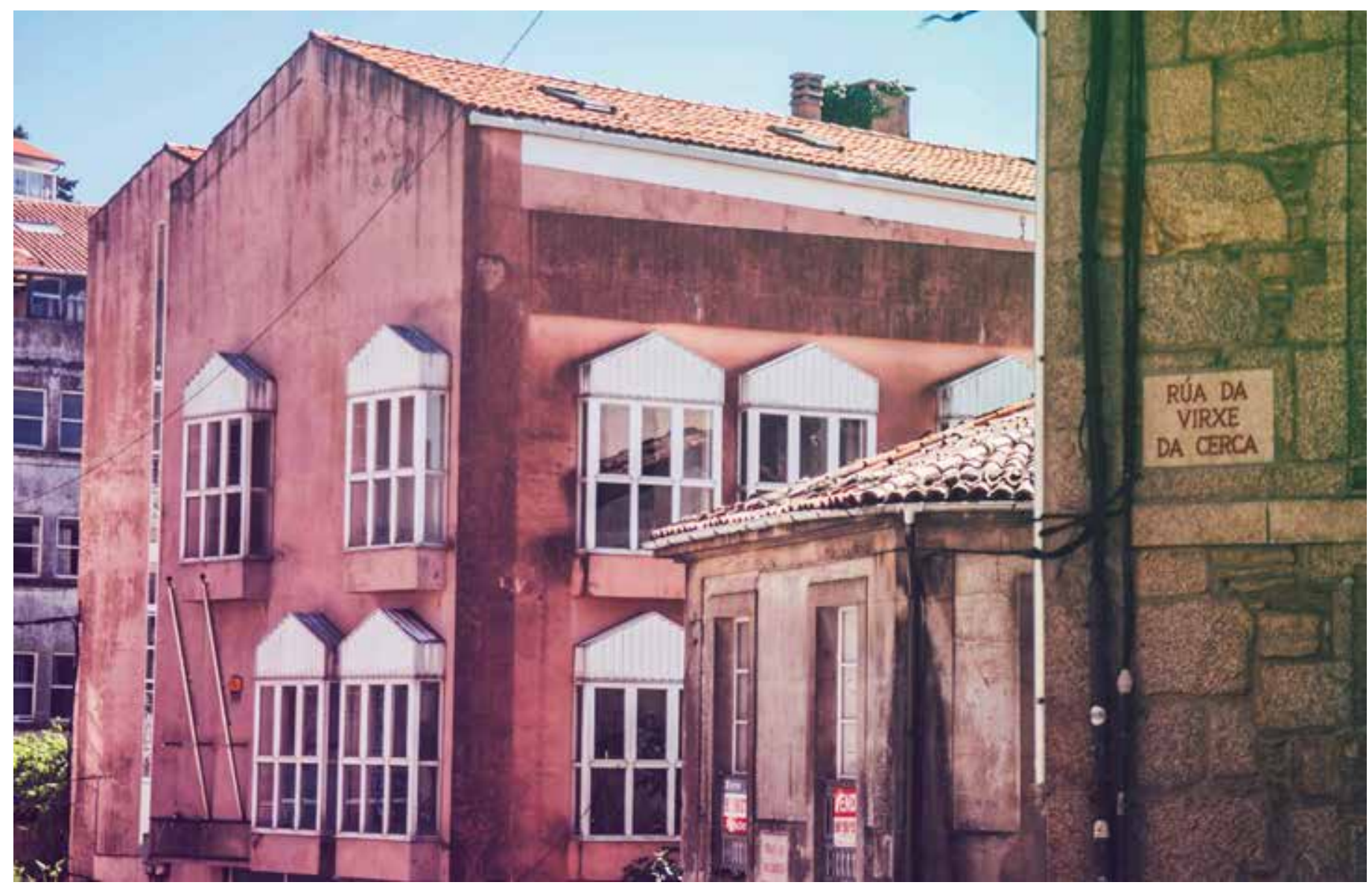

This fact contrasts with masculine figures names, which are primarily renowned civil characters i. e. men with positions of economic or political power or reputable intellectuals, with a greater variety of occupations than the women represented.

The names of intellectual women recently added to the city of Santiago de Compostela's street nomenclature try to offer alternative forms of resistance that prevents the city to be close to the even worse numbers shown by other Galician capitals, as Pontevedra or Ourense. Nevertheless, compared with other Spanish cities, data indicates that this situation is a generalized picture of an adverse situation.

This fact, in a human reality of great diversity, claims an androcentric bias in the methodology of commemorative urban practices. The case of Santiago de Compostela is only one example of a generally established and widespread situation: human collective memory in urban spaces is still predominately masculine; excluding marginalized social groups from recognition procedures and restricting the inclusion of alternative stories, those that go unnoticed for centuries, by considering them inconvenient.

Commemorative urban practices are a social constructed system. They were born from the structures of power in the context of the
Figure 8: Rúa da Virxe da Cerca / Virxe da Cerca Street. Source: photo by the author, Santiago de Compostela, 2017. 
French Revolution, and they continue to validate and legitimise a certain political representation of history in public spaces. However, this authoritarian perspective is based on the myth of objectivity. Administrative regulated recognition process is not neutral or impartial, but rather exemplifies an allegory, specifically an androcentric allegory, of a hegemonic version of history.

According to Donna Haraway, a doctrine of objectivity from a feminist-based perspective means situated knowledge. Situated perspectives versus objectivity transcend commonly presumed truths, as a way to ensure an ethical, plural and more inclusive narrative of collective memory.

In addition, it is essential to overcome systemic exclusion of women by their confinement to private and domestic spheres. For centuries, biologically-determined theories have considered women as submissive, subjective and home-oriented beings, naturalising their belonging to domestic spaces and reserving active public life exclusively for men. However, public spaces are where power becomes evident — it is the domain where social recognition and values take place-. In contemporary political culture, lack of women in urban commemorative processes and toponymic inscription of feminine odonyms through neotoponimy or renaming, can no longer be admitted, although it continues to exist.

Despite the unfavourable picture, we must not forget that collective memory is a living social construction, a sphere where people can dispute supremacies and re-establish the links between the past, the present and the future. This means that people can actively change authority discourse through critical and situated perspectives struggling in the cultural arena of commemorative urban practices. In terms of the right to participate, potential transformations are possible in order to shape cities' futures and turn them into inclusive and fair territories, as in the case of Santiago de Compostela.

\section{Recommendations for future research}

In order to advance towards real effective equality in territories, studies can be done in the future to address this issue from a gender-based perspective in Santiago de Compostela, such as: (1) to investigate the special distribution of thoroughfares based on gender and the social implications of their centrality or peripheral location, as studying the segregated geography of toponyms, "where they are located and, even more importantly, where they are not - can advance or obstruct the realization of the political goals of historically marginalized social groups" (Alderman \& Inwood, 2013, p. 218); (2) to delve into profiles of historical figures, and the political reasons that cause the androcentric bias in their social recognition process; (3) to extend the analysis of symbolic representations of women and historically marginalized groups' collective memory in urban spaces to commemorate public art such as monuments or the names of single buildings or, finally, (4) to explore the temporal dimension, from a historiographic perspectives, that involves the study of the evolution feminine toponyms and the first female pioneers honoured by naming elements in urban public spaces.

\section{Alternatives for the future}

In response to this generalized situation of inequality, some city councils have been pioneers in establishing specific corrective measures that promote more spatial justice contexts regarding gender. 
The project São Paulo 16\% denounces how " $84 \%$ of streets that commemorate enlightened people in São Paulo refer to men" ('Estadão' \& FCB Brazil, 2017). ${ }^{11}$ On this occasion, O Estadão and FCB Brazil started the enterprise \#SomosMaisQue16porcento (\#WeAreMoreThan16percent) in 2017, "an initiative to make the city more and more diverse" (ibíd.). Thus, through its site 16porcento.com.br citizens can participate in voting or indicating women that are worth commemorating. The ultimate goal is to "deliver a document with all the voted-for names to the Câmara de Vereadores" (ibíd.) and transform reality, making alternative stories evident.
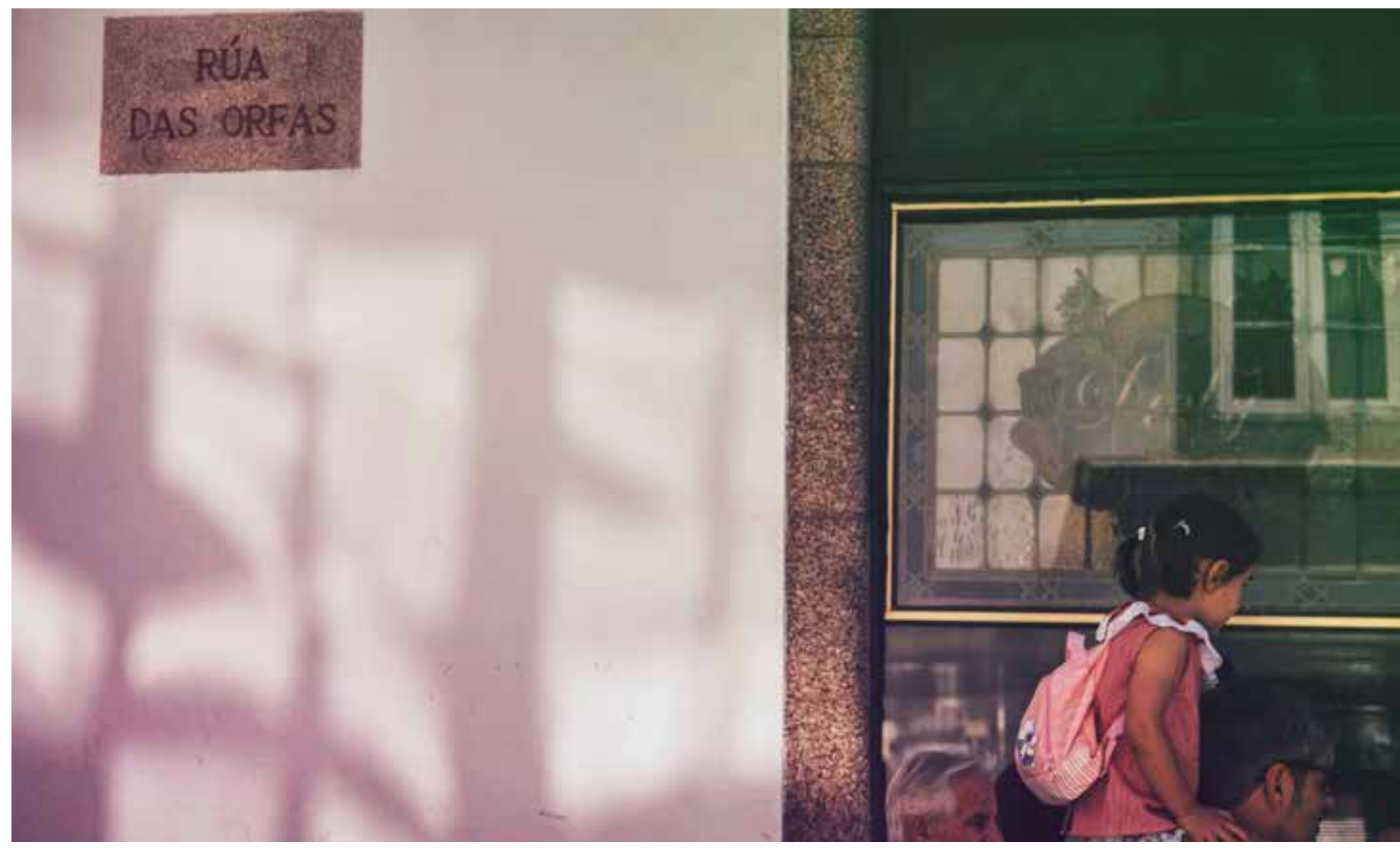

Other cities such as Florence, in Italy, established municipal regulations in order to achieve gender parity by dedicating $50 \%$ of urban anthroponyms to women. This initiative was promoted by a councillor after verifying that out of two hundred new toponyms, only twelve were feminine (EFE, 2008). In this case, it should be noted that women's participation in decision-making processes promotes a more inclusive symbolic presence of human figures in the city.

To conclude, collective spatial narratives in public space belongs to the people, as a bridge between past and future that we must re-establish in order to promote definitive spatial justice, and thus fairer societies. In the construction of a more inclusive and diverse territory, we must address urgent ethical questions while acknowledging different inhabitants' identities. From this point on, situated perspectives will be valuable for building public urban spaces that can be, once and for all, a pathway to a future of equality.

Acknowledgements: This work was supported by the Department of Equality, Economic Development and Tourism of the City Council of Santiago de Compostela, under the initiative "Compostela, Women's Terrain".
Figure 9: Rúa das Orfas / Orfas Street. Source: photo by the author, Santiago de Compostela, 2017

11 Quotations translated from Portuguese by the author from the original text " $84 \%$ das ruas que homenageiam pessoas ilustres em São Paulo se referem a homens. Tá na hora de mudar esse número. O Estadão está lançando o Projeto \#SomosMaisQue16porcento, uma iniciativa para tornar a cidade cada vez mais diversa. Participe votando e/ou indicando grandes mulheres que fizeram parte da história e merecem ter seu nome nas ruas de São Paulo. No final, entregaremos um documento com todos os nomes votados para a Câmara de Vereadores. Depois disso, não existirão mais desculpas para que essa estatística continue assim”. 


\section{References}

Alderman, D. H. e Inwood, J. (2013). Street naming and the politics of belonging: Spatial injustices in the toponymic commemoration of Martin Luther King Jr. Social and Cultural Geography, 14(2), 211233. DOI: https://doi.org/10.1080/14649365.201 2.754488.

Arias Chachero, P. (2007). Mulleres na Rúa: Sobre Toponimia Urbana. Andaina, Revista galega de pensamiento feminista, 46, 46-49. Recuperado el 12 de agosto de 2018, de: https://issuu.com/petapouca/ docs/andaina_46.

Azaryahu, M. (1986). Street Names and Political Identity: The Case of East Berlin. Journal Of Contemporary History, 21(4), 581-604.

Azaryahu, M. (1996). The Power of Commemorative Street Names. Environment and Planning D: Society and Space, 14, 311-330.

Azaryahu, M. y Foote, K. E. (2008). Historical space as narrative medium: On the configuration of spatial narratives of time at historical sites. GeoJournal, 73(3), 179-194.

Boullón Agrelo, A. I. y Tato Plaza, F. R. (1998-1999). Personal names in Galicia as a sign of cultural identification: Historical scope and current situation. Onoma, 34, 15-44. DOI: https://doi.org/10.2143/ ONO.34.0.2003438.

Concello de Santiago de Compostela (2012). Proposta da alcaldía de nomes para as novas rúas en Santiago de Compostela, Recuperado el 12 de agosto de 2018, de: http://www.santiagodecompostela.gal/ imxd/noticias/doc/1330020429ruas_def.pdf.

De la Cruz, F.J. (ed.) (n.d.), Palencia y sus calles, una cuestión de género [en línea]. Recuperado el 12 de agosto de 2018, de: https://sites.google.com/site/ callespalencia/home.

EFE (2008, 28 de octubre). La paridad de género llega a los nombres de las calles de Florencia, El País digital [en línea]. Recuperado el 12 de agosto de 2018, de: http:/ / sociedad.elpais.com/socie$\mathrm{dad} / 2008 / 10 / 28 /$ actualidad/1225148404_850215. html.

Eldestein, J. (2017, 7 de marzo). Sólo el 3,2 \% de las calles cordobesas llevan nombre de mujer. La Voz [en línea]. Recuperado el 12 de agosto de 2018, de: http:/ / www.lavoz.com.ar/ciudadanos/solo-el32-de-las-calles-cordobesas-llevan-nombre-de-mujer.

'Estadão' y FCB Brazil (2017). Projecto 16\%. Recuperado el 12 de junio de 2018, de: http:/ /16porcento. com.br/.

Estrada, J. (2007, 10 de octubre). Los símbolos franquistas se fueron de Santiago sin hacer mucho ruido. El Correo Gallego. Recuperado el 12 de agosto de 2018, de: http://www.elcorreogallego.es/san- tiago/ecg/simbolos-franquistas-fueron-santiagohacer-mucho-ruido/idEdicion-2007-10-20/idNoticia-222457/.

Foote, K. E. y Azaryahu, M. (2007). Toward a Geography of Memory: Geographical Dimensions of $\mathrm{Pu}-$ blic Memory and Commemoration. Journal of Political and Military Sociology, 35(1), 1-20.

Giraut, F. y Houssay-Holzschuch, M. (2008a). Au nom des territoires! Enjeux géographiques de la toponymie. Espace Géographique, 2(37), 97-105.

Giraut, F. y Houssay-Holzschuch, M. (2008b). Néotoponymie: formes et enjeux de la dénomination des territoires émergents. L'Espace Politique, 5(2), 1-8. DOI: https://doi.org/10.4000/espacepolitique.161.

Giraut, F. y Houssay-Holzschuch, M. (2016). Place Naming as Dispositif: Toward a Theoretical Framework. Geopolitics, 21(1), 1-21. DOI: https:/ / doi. org/10.1080/14650045.2015.1134493.

Giraut, F. y Houssay-Holzschuch, M. (2017). Au-delà du toponyme, la dimension politique de la territorialisation par la nomination. En Pasquali, S. y González, J. (eds.), Actes du Colloque: Au delà du Toponyme. Approche interdisciplinaire de la territorialité. Egypte et Méditerranée anciennes. Montpellier. [s.1.]: [s.n.]. Recuperado el 10 de agosto de 2018, de: https:/ / archive-ouverte.unige.ch/unige:89474.

Guerra Palmero, M.J. (1999). Mujer, Identidad y Espacio Público. Contrastes: Revista Interdisciplinar de Filosofia, 4, 45-64.

Haraway, D. (1988). Situated Knowledges: The Science Question in Feminism and the Privilege of Partial Perspective. Feminist Studies, 14, 575-599. DOI: https://doi.org/10.2307/3178066.

Hayden, Dolores (1997). The Power of Place: Urban Landscapes as Public History. Cambridge, Massachusetts: The MIT Press.

Kuri Pineda, E. (2013). Representaciones y significados en la relación espacio-sociedad: una reflexión teórica. Sociológica, 28(78), 69-98. Recuperado el 12 de agosto de 2018, de: http:/ / www.scielo.org.mx/ pdf/soc/v28n78/v28n78a3.pdf.

Kuri Pineda, E. (2017). La Construcción Social de la Memoria en el Espacio: una Aproximación Sociológica. Península, 12(1), 9-30. DOI: https://doi. org/10.1016/j.pnsla.2017.01.001.

Ley 52/2007, de 26 de diciembre, por la que se reconocen y amplían derechos y se establecen medidas en favor de quienes padecieron persecución o violencia durante la guerra civil y la dictadura, Boletín Oficial del Estado n. ${ }^{\circ} 303$, de 27 de diciembre de 2007, 53410-53416. Recuperado el 12 de agosto de 2018, de: http:/ / www.boe.es/boe/ dias/2007/12/27/pdfs/A53410-53416.pdf. 
Light, D. y Young, C. (2014). Toponymy as Commodity: Exploring the Economic Dimensions of Urban Place Names. International Journal of Urban and Regional Research, 39(3), 435-450. DOI: https://doi. org/10.1111/1468-2427.12153.

Llaneras, K. y Pérez Colomé, J. (2017, 7 de enero). Ellos son doctores, ellas vírgenes y santas. El País digital [en línea]. Recuperado el 12 de agosto de 2018, de: http:/ / politica.elpais.com/politica/2017/01/06/actualidad/1483666778_781495.html.

Rose-Redwood, R., Alderman, D. y Azaryahu, M. (2010). Geographies of toponymic inscription: New directions in critical place-name studies. Progress in Human Geography, 34(4), 453-470. DOI: https:/ / doi.org/10.1177/0309132509351042.

Rose-Redwood, R. (2011a). Critical Interventions in Political Toponymy. ACME: An International E-Journal for Critical Geographies, 10(1), 1-6.

Rose-Redwood, R. (2011b). Rethinking the agenda of political toponymy. ACME: An International E-Journal for Critical Geographies, 10(1), 34-41.
Sánchez, V.S. (2016, 24 de noviembre). ¿Cuántas calles de Barcelona tienen nombre de mujer? El Periódico [en línea]. Recuperado el 12 de agosto de 2018, de: http:/ / www.elperiodico.com/es/noticias/extra/calles-barcelona-nombre-mujer-5649804.

Shoval, N. (2013). Street-naming, tourism development and cultural conflict: the case of the Old City of Acre / Akko / Akka. Transactions of the Institute of British Geographers, 38(4), 612-626. DOI: https:// doi.org/10.1111/tran.12003.

Tucker, B. y Rose-Redwood, R. (2015). Decolonizing the map? Toponymic politics and the rescaling of the Salish Sea. The Canadian Geographer, 59(2), 194206. DOI: https://doi.org/10.1111/cag.12140.

Wingley, M. (1992). Untitled: The Housing of Gender. En Colomina, B. (ed.), Sexuality E Space. New York: Princeton Architectural Press, 327-389.

Yanushkevich, I. (2014). Semiotics of Social Memory in Urban Space: The Case of Volgograd (Stalingrad). International Journal of Cognitive Research in Science, Engineering and Education, 2, 43-50.

Novas Ferradás, M. (2018). Commemorative Urban Practices and Gender Equality: The Case of Santiago de Compostela's Urban Anthroponymy. Hábitat y Sociedad, 11, 109-129.

<http://dx.doi.org/10.12795/HabitatySociedad.2018.i11.07> 


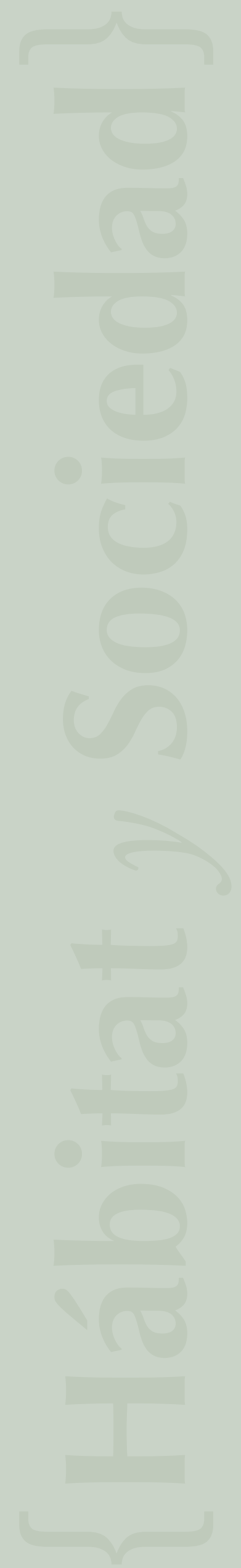

